\title{
MicroRNA-mediated regulation of IL-10, IL-12 and TNF $\alpha$ gene expression in severely injured trauma patients
}

\author{
Timothy F Jones ${ }^{1,2^{*}}$, Helen C Owen ${ }^{1}$, Hew DT Torrance ${ }^{1,2,3}$, Negar Pirmadjid ${ }^{1}$, Karim Brohi ${ }^{2}$, Charles J Hinds ${ }^{1,3}$, \\ Michael J O'Dwyer ${ }^{1,3}$
}

From London Trauma Conference 2014

London, UK. 9-12 December 2014

\section{Background}

Severe trauma induces a blunted immune response associated with an enhanced susceptibility to nosocomial infections [1]. Within 2 hours of injury, expression of the prototypical anti-inflammatory cytokine, IL-10, increases whilst expression of the pro-inflammatory cytokines, TNF $\alpha$ and IL-12, decreases [1]. We hypothesise that microRNAs (miRs) may exacerbate this immunosuppressive gene expression pattern.

\section{Methods}

Following ethical approval and consent, 30 ICU patients admitted following trauma and 16 healthy age and sexmatched controls were recruited. Blood samples were obtained within 2 hours of injury and at 24 hours. miRs were isolated using PAXGene (Qiagen). miRs were selected on the basis of their miRBase target prediction scores for the promoters of IL-10, IL-12 and TNF $\alpha$. Six miRs selected for analysis were miR374b, -202 and 125a3p (IL-10), -410 and -21 (IL-12) and -454 (TNFa). qPCR was used to quantify candidate miRs and the results were normalised relative to small nucleolar RNAs U6/RNU44. Infections were assessed using predefined criteria [2].

\section{Results}

Twenty three patients (77\%) developed an infection, $15(50 \%)$ were shocked (base deficit $\geq 6 \mathrm{mEq} / \mathrm{L}$ ) on admission and 6 (20\%) died. Within 2 hours,

\footnotetext{
* Correspondence: t.jones@smd11.qmul.ac.uk

${ }^{1}$ Centre for Translational Medicine and Therapeutics, William Harvey Research Institute, Barts and the London School of Medicine and Dentistry, London, UK

Full list of author information is available at the end of the article
}

expressions of miR-202, -125a3p, -21 and -454 were reduced (all $\mathrm{p}<0.03$ ) in patients compared to healthy controls. This reduction was maintained (all $\mathrm{p}<0.01$ ) 24 hours after injury. At 24 hours, miR-202 was downregulated (2.4-fold, $\mathrm{p}=0.01)$ in shocked compared to non-shocked patients. Decreased miR-374b expression on admission was associated with subsequent development of pneumonia $(\mathrm{p}=0.009)$.

\section{Conclusion}

Expression of miRs complementary to cytokine promoters varies significantly following severe traumatic injury and is associated with clinical outcomes. Reduction in inhibitory miRs could partly explain increased IL-10 expression and provide a mechanistic link between severe trauma, the observed immunosuppressive phenotype and an increased incidence of nosocomial infections. In vitro studies are now needed to invoke causation.

\section{Authors' details \\ 'Centre for Translational Medicine and Therapeutics, William Harvey Research Institute, Barts and the London School of Medicine and Dentistry, London, UK. ${ }^{2}$ Centre for Trauma Sciences, Blizard Institute, Barts and the London School of Medicine and Dentistry, London, UK. ${ }^{3}$ Adult Critical Care Unit, Royal London Hospital, Barts Health NHS Trust, London, UK.}

Published: 11 September 2015

\section{References}

1. Torrance HD, Brohi K, Pearse RM, Mein CA, Wozniak E, Prowle J, Hinds CJ, O\&Dwyer MJ: Association between gene expression biomarkers of immunosuppression and blood transfusion in severely injured polytrauma patients. Ann Surg, in press.

2. Horan TC, Andrus M, Dudeck MA: CDC surveillance definition of healthcare-associated infection and criteria for specific types of
C Biomed Central

(c) 2015 Jones et al. This is an Open Access article distributed under the terms of the Creative Commons Attribution License (http:// creativecommons.org/licenses/by/4.0), which permits unrestricted use, distribution, and reproduction in any medium, provided the original work is properly cited. The Creative Commons Public Domain Dedication waiver (http://creativecommons.org/publicdomain/ zero/1.0/) applies to the data made available in this article, unless otherwise stated. 
infections in the acute care setting. Am J Infect Control 2008, 36:309-332.

doi:10.1186/1757-7241-23-S2-05

Cite this article as: Jones et al:: MicroRNA-mediated regulation of IL-10,

IL-12 and TNF $\alpha$ gene expression in severely injured trauma patients.

Scandinavian Journal of Trauma, Resuscitation and Emergency Medicine 2015

23(Suppl 2):05

Submit your next manuscript to BioMed Central and take full advantage of:

- Convenient online submission

- Thorough peer review

- No space constraints or color figure charges

- Immediate publication on acceptance

- Inclusion in PubMed, CAS, Scopus and Google Scholar

- Research which is freely available for redistribution

Submit your manuscript at 